\title{
$\mathrm{Nb}_{\mathrm{ss}} / \mathrm{Nb}_{5} \mathrm{Si}_{3}$ 合金のクリープ破断特性におよぼす Mo, W および(Nb, Hf)C の影響
}

田中久男 ${ }^{1} \quad$ 金 $\quad$ 元 鎔 1 ,* $^{\text {藤 } \text { 倉 正 国 }^{1} \quad \text { 田中良平 }{ }^{1} \text { 三島 良 直 }}{ }^{2}$

1株式会社超高温材料研究所

2 東京工業大学大学院総合理工学研究科

J. Japan Inst. Metals, Vol. 67, No. 8 (2003), pp. 385-390

(C) 2003 The Japan Institute of Metals

\section{Effects of Mo, W and ( $\mathrm{Nb}, \mathrm{Hf}) \mathrm{C}$ on Creep Rupture Properties of $\mathrm{Nb}_{\mathrm{ss}} / \mathrm{Nb}_{5} \mathrm{Si}_{3}$} In-Situ Composites

Hisao Tanaka ${ }^{1}$, Won-Yong Kim ${ }^{1, *}$, Masakuni Fujikura ${ }^{1}$, Ryohei Tanaka ${ }^{1}$ and Yoshinao Mishima ${ }^{2}$

${ }_{1}^{1}$ Japan Ultra-high Temperature Materials Research Institute (JUTEMI), Ube 755-0001

${ }^{2}$ Department of Materials Science and Engineering, Tokyo Institute of Technology, Yokohama 226-8502

The high-temperature tensile creep rupture properties of the $\mathrm{Nb}$ solid solution in-situ composites $\left(\mathrm{Nb}_{\mathrm{ss}}\right) / \mathrm{Nb}_{5} \mathrm{Si}_{3}$ and $\mathrm{Nb}_{\mathrm{ss}} /$ $\mathrm{Nb}_{5} \mathrm{Si}_{3} /(\mathrm{Nb}, \mathrm{Hf}) \mathrm{C}$ have been studied in relation to their chemical compositions and microstructures. The samples were prepared by arc melting. $\mathrm{Nb}_{\mathrm{ss}} / \mathrm{Nb}_{5} \mathrm{Si}_{3}$ in-situ composites alloyed with $\mathrm{Mo}$ and $\mathrm{W}$ have a maze-like structure. Small dispersed carbide regions were mainly observed in $\mathrm{Nb}$ solid solution and phase boundary in the $\mathrm{Nb}_{\mathrm{ss}} / \mathrm{Nb}_{5} \mathrm{Si}_{3} /(\mathrm{Nb}, \mathrm{Hf}) \mathrm{C}$ in-situ composites. Additionally, carbides precipitated inside the silicide region after the creep rupture test. High-temperature tensile creep tests were conducted at $1773 \mathrm{~K}$ under argon over a stress range from 20 to $200 \mathrm{MPa}$. We found that $\mathrm{Nb}-16 \mathrm{Si}-5 \mathrm{Mo}-15 \mathrm{~W}-5 \mathrm{Hf}-5 \mathrm{C}$ has a high creep rupture strength, with a time-to-rupture of $477 \mathrm{~h}$ at $1773 \mathrm{~K}$ under a stress $100 \mathrm{MPa}$. Addition of $\mathrm{W}$ is more effective than Mo to increase on creep strength at $1773 \mathrm{~K}$, and the rupture time was prolonged at lower stress in $\mathrm{Nb}-20 \mathrm{Si}-5 \mathrm{Mo}-5 \mathrm{Hf}-5 \mathrm{C}$ triphase alloy with a dispersion of $(\mathrm{Nb}, \mathrm{Hf}) \mathrm{C}$ carbide particles.

(Received April 10, 2003; Accepted June 2, 2003)

Keywords: niobium alloys, niobium silicide, solid solution strengthening, dispersion strengthening, creep rupture strength, minimum creep rate, carbide

\section{1. 緒言}

二酸化炭素排出量の削減と化石燃料資源節約の観点から, 電力分野では複合サイクル発電の活用と，それに用いられる ガスタービンの運転温度の上昇による熱効率の一層の改善が 求められている. 現在, ガスタービンをはじめとする高温機 器の構造材料としては, $\mathrm{Ni}$ 基超合金が主流となってはいる が，現用の超合金を用いる限り， $1300 \mathrm{~K}$ 以上での長期間の 使用には冷却システムが不可欠であり，そのためガスタービ ンの運転温度の上昇による熱効率の改善も限界に近いと言わ ざるを得ない.

そこで著者らは, Nbを主成分とする超合金の開発を意図 し一連の研究を行なってきた ${ }^{1-7)}$. 金属 $\mathrm{Nb}$ は高温における 耐酸化性に大きな問題はあるものの, その融点は $\mathrm{Ni} よ り$ $1000 \mathrm{~K}$ あまり高く, 密度もやや小さい上に延性に富むこと から， $\mathrm{Nb}$ 基超合金は $\mathrm{Ni}$ 基超合金を超える高温構造材料と して有望と考えられるからである.これまでの研究結果から Mo と W の組み合わせ添加による固溶強化に加えて, シリ

\footnotetext{
* NEDO Fellow, Present: Advanced Materials Research and De-
} velopment Center, Korea Institute of Industrial Technology
サイド $\mathrm{Nb}_{5} \mathrm{Si}_{3}$ の分散が高温強度の改善に有利であること, また $\mathrm{Nb}$ 固溶体 (以下 $\mathrm{Nb}_{\mathrm{ss}}$ と表記する) 相中に炭化物を析出 させると高温での粒界強度は向上することを明らかにしてき た

$\mathrm{Nb}$ 基超合金に関連して $\mathrm{Nb}_{3} \mathrm{Al}$ や $\mathrm{Nb}_{5} \mathrm{Si}_{3}$ などの $\mathrm{Nb}$ 基金 属間化合物と $\mathrm{Nb}_{\mathrm{ss}}$ との複合材料の開発が報告されてい る ${ }^{8-11)}$.これらは $\mathrm{Nb} の$ 延性と金属間化合物の高温強度の両 立をはかったものと言えるが，超高温用の構造材料に必須な $1500 \mathrm{~K}$ を超える超高温における引張クリープ特性について はまったく報告されていない.

そこで本研究では， $\mathrm{Nb}$ 基超合金開発の一環として，Mo

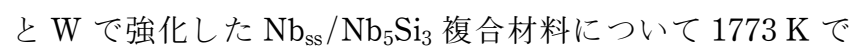
のクリープ特性を調べ，合金元素と組織因子の役割について 考察するとともに, Hf と C を組み合わせ添加して炭化物 (Nb, Hf) C を分散させた $\mathrm{Nb}_{\mathrm{ss}} / \mathrm{Nb}_{5} \mathrm{Si}_{3} /(\mathrm{Nb}, \mathrm{Hf}) \mathrm{C}$ の三相を 含む複合材料が著しく優れたクリープ特性を有することを見 い出したので，ここに報告する.

\section{2. 実 験 方 法}

本研究で用いた合金の配合組成を, まとめて Table 1 に示 
Table 1 Nominal composition of Nb-based alloys.

\begin{tabular}{ll} 
& \multicolumn{1}{c}{$(\mathrm{mol} \%)$} \\
\hline Nb-20Si-5Mo & Nb-16Si-5Mo-5W \\
Nb-20Si-10Mo & Nb-16Si-5Mo-10W \\
Nb-20Si-5Mo-2.5Hf-2.5C & Nb-16Si-5Mo-15W \\
Nb-20Si-5Mo-5Hf-5C & Nb-16Si-5Mo-15W-5Hf-5C \\
\hline
\end{tabular}

す． Si は亜共晶組織と過共晶組織になるようにそれぞれ 16 mol\%と $20 \mathrm{~mol} \%$ 添加した。純度 99.9 mass\%の塊状 $\mathrm{Nb}$, Mo と W，純度 98 mass\%のスポンジ状の Hf，純度 99.999 mass\%の塊状 Si 抢よび純度 $98 \mathrm{~mol} \%$ の粉末 $\mathrm{NbC}$ を原料と して，目的組成に配合しアーク溶解した。 引張クリープ試験 用素材は，小さなボタン状インゴットを 10 個程度，斜めに 重なり合うようにして銅ハース上に一列に並べ，一定の速度 で電極を移動させながら細長い板状にアーク溶解し，反転を 5 回以上繰り返して溶製した。アーク炬には， 2 本の $\mathrm{W}$ 電 極があり，そのうち 1 本は䨌囲気中の酸素量を低減するた めのゲッター用 Ti を常時溶解しながら, 他の電極でインゴ ットを溶解した，板状のインゴットの大きさは，およそ長さ $150 \mathrm{~mm}$, 幅 $30 \mathrm{~mm}$, 厚さが $8 \mathrm{~mm}$ であった. インゴット は，均質化のために $2123 \mathrm{~K}$ ，アルゴン䨌囲気中で $48 \mathrm{~h}$ 熱処 理して炉冷した.クリープ試験片は, ワイヤ放電加工機で切 出し，その後エメリ一紙で表面を研磨した．相の定量分析は EPMA の WDS で，相の定性分析は X 線回折で行ない，組 織は主として反射電子線像 $(\mathrm{BEI})$ で観察した. 引張クリープ 試験片は，平行部寸法が $3 \mathrm{~mm} \times 3 \mathrm{~mm} \times 10 \mathrm{~mm}$ (標点間距離 は $10 \mathrm{~mm}$ )で，全長 $80 \mathrm{~mm}$ とし，クリープひずみを計測す るために左右上下にフラグをつけた。 $1300 \mathrm{~K}$ を超える温度 でのクリープひずみの計測には，従来の接触式ひずみ計はそ の耐熱性の点から使用できないため，2つの CCD カメラを 有する光学式の画像变位計を用いてフラグ間の距離を測定し た。ただし，空ガラスの曇りが発生した場合，測定ができな くなるという久点がある.引張クリープ破断試験は東伸工業 社製の試験機(型式：HCTT-3000)で縦型両てこ荷重式を用 い, 試験応力を $20 \sim 200 \mathrm{MPa}$, 試験温度 $1773 \mathrm{~K}$ ，アルゴン 中で定荷重のクリープ試験を行ない，クリープひずみの経時 変化とクリープ破断時間を求めた。また，クリープ試験後の 破断部近傍の組織は BEI で, クリープ破断面は二次電子線 像 (SEM)で観察した。

\section{3. 結果と考察 \\ 3.1 組織と構成相}

$\mathrm{Si}$ 量や添加元素による $\mathrm{Nb}$ 基合金の組織の形状と構成相を 明らかにするために，組織観察および X 線回折を行なっ た. クリープ試験後の試験片つかみ部分の代表的な組織と X 線回折結果をそれぞれ Fig. 1 と Fig. 2 に示す。これらの 組織は $2123 \mathrm{~K}$ で均質化処理を施したままの組織とほとんど 変わっていないため, それぞれクリープ破断の時間だけ $1773 \mathrm{~K}$ で時効したときの組織とみなすことができる. 構成 相の同定を X 線回折と EPMA で行なった結果, $\mathrm{Nb}-16 \mathrm{Si}-$ 5Mo-5W (Fig. 1 (a)) と Nb-20Si-10Mo(Fig. 1(b)) は二相か らなり, コントラストの暗い部分は $\alpha-\mathrm{Nb}_{5} \mathrm{Si}_{3}$, 明るい部分 は $\mathrm{Nb}_{\mathrm{ss}}$ である。 また, Hf と C を添加した $\mathrm{Nb}-16 \mathrm{Si}-5 \mathrm{Mo}-$ 15W-5Hf-5C (Fig. 1 (c)) は三相からなり，コントラストの 暗い部分は $\alpha-\mathrm{Nb}_{5} \mathrm{Si}_{3}$, 中間色の部分が $\mathrm{Nb}_{\mathrm{ss}}$ で, 明るい部分 は炭化物 $(\mathrm{Nb}, \mathrm{Hf}) \mathrm{C}$ である. 炭化物は, $\mathrm{Nb}_{\mathrm{ss}}$ の結晶粒界や シリサイドとの界面に分散している. 本研究で評価した 16 at $\% \mathrm{Si}$ を含む合金はすべて亜共晶組織で, 粗大な初晶は $\mathrm{Nb}_{\mathrm{ss}}$ である. 一方, $20 \mathrm{at} \% \mathrm{Si}$ を含むものは過共晶組織で, 初晶は $\mathrm{Nb}_{5} \mathrm{Si}_{3}$ である.

$\mathrm{Nb}-16 \mathrm{Si}-5 \mathrm{Mo}-5 \mathrm{~W}$ と $\mathrm{Nb}-16 \mathrm{Si}-5 \mathrm{Mo}-15 \mathrm{~W}-5 \mathrm{Hf}-5 \mathrm{C}$ の EPMA による定量分析の結果を Table 2 に示す. Nb-16Si$5 \mathrm{Mo}-5 \mathrm{~W}$ の $\mathrm{Nb}_{\mathrm{ss}}$ 中の $\mathrm{Si}$ 量抢よび $\mathrm{Nb}_{5} \mathrm{Si}_{3}$ 中の $\mathrm{Mo}$ と $\mathrm{W}$ 量 は，ともに僅かである。つまり， $\mathrm{Nb}_{\mathrm{ss}} / \mathrm{Nb}_{5} \mathrm{Si}_{3}$ 二相合金に添 加した Mo と W は, ほとんどが Nbに固溶し, Si はほとん どシリサイド形成に費やされている。 また， Nb-16Si-5Mo15W-5Hf-5Cでも， $\mathrm{Nb}_{\mathrm{sS}}$ 中に Mo や W は多く含まれるが， $\mathrm{Si}, \mathrm{Hf}$ 抢よび C は極めて少ない。一方, $\mathrm{Nb}_{5} \mathrm{Si}_{3}$ 中には $\mathrm{Mo}$ と W 量は僅かであるが, 約 $7 \mathrm{~mol} \%$ O H と C が含まれて いる. さらに，コントラストの最も明るい部分の炭化物には, Mo と W の固溶量はごく少なく, また Si もほとんど含まれ ず， $37 \mathrm{~mol} \%$ のb と $15 \mathrm{~mol} \%$ のf が含まれており，X 線

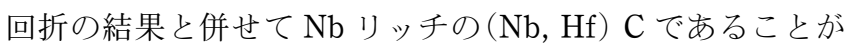
わかる。つまり, 添加した Mo や W はほとんど Nbに固溶 するが，Hfの固溶量はごく少ない。その $\mathrm{Hf}$ の大半は $\mathrm{Nb}$ 炭 化物中に固溶している. また $\mathrm{Hf}$ と $\mathrm{C}$ は $\mathrm{Nb}_{5} \mathrm{Si}_{3}$ にも固溶し ている.
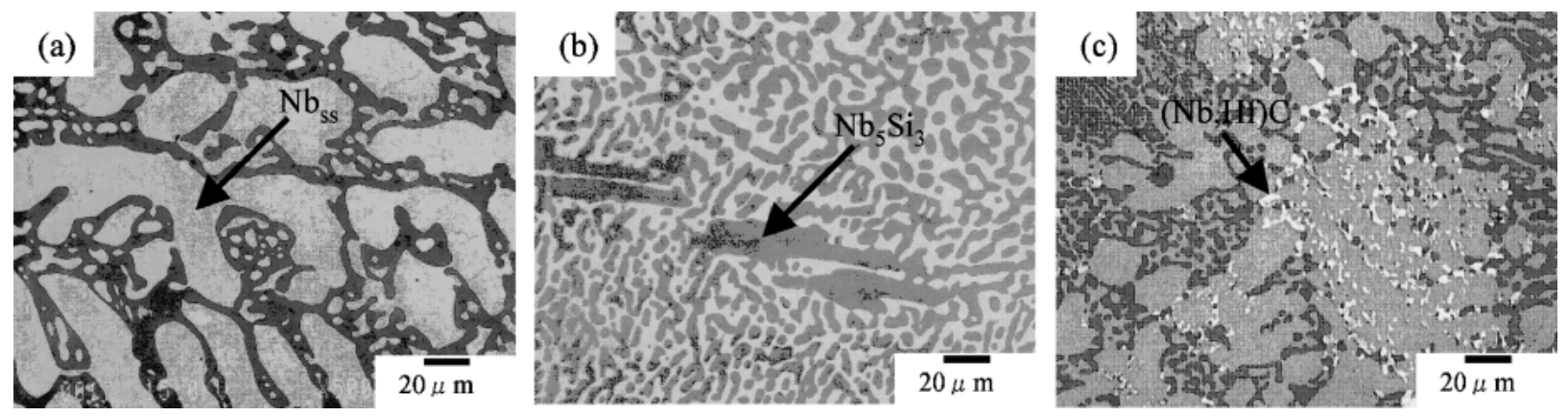

Fig. 1 BEI images of three alloys.

(a) $\mathrm{Nb}-16 \mathrm{Si}-5 \mathrm{Mo}-5 \mathrm{~W}$, aged at $1773 \mathrm{~K}$ for $62 \mathrm{~h}$. (b) $\mathrm{Nb}-20 \mathrm{Si}-10 \mathrm{Mo}$, aged at $1773 \mathrm{~K}$ for $58 \mathrm{~h}$. (c) $\mathrm{Nb}-16 \mathrm{Si}-5 \mathrm{Mo}-15 \mathrm{~W}-5 \mathrm{Hf}-5 \mathrm{C}$, aged at $1773 \mathrm{~K}$ for $477 \mathrm{~h}$. 


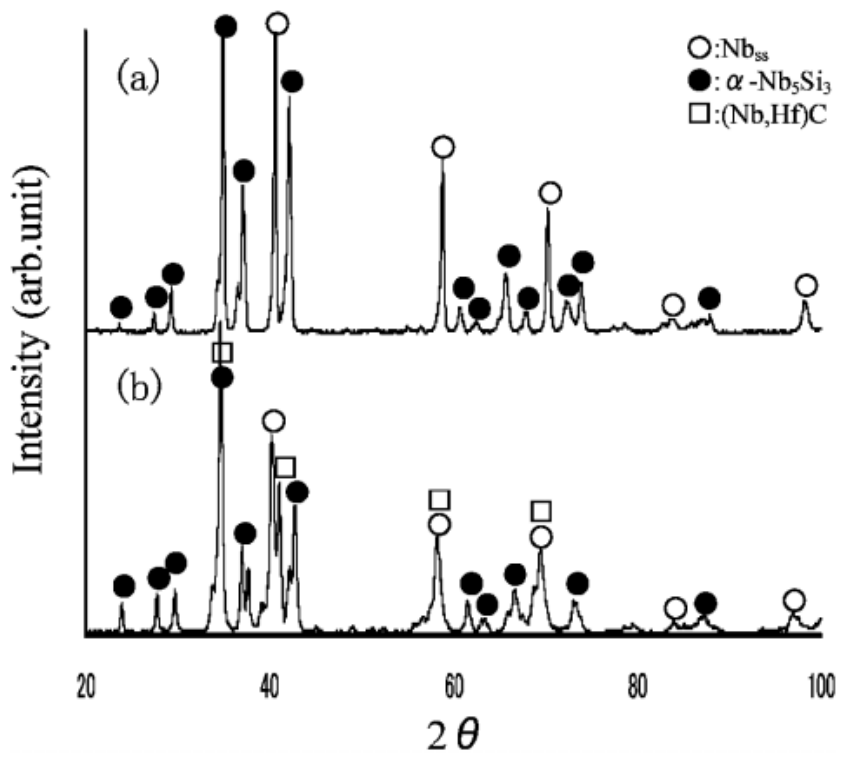

Fig. $2 \quad \mathrm{X}$-ray diffraction spectra.

(a) $\mathrm{Nb}-20 \mathrm{Si}-10 \mathrm{Mo}$, aged at $1773 \mathrm{~K}$ for $58 \mathrm{~h}$, (b) $\mathrm{Nb}-16 \mathrm{Si}-$ $5 \mathrm{Mo}-15 \mathrm{~W}-5 \mathrm{Hf}-5 \mathrm{C}$, aged at $1773 \mathrm{~K}$ for $477 \mathrm{~h}$.

Table 2 Chemical composition of phases in $\mathrm{Nb}$-based alloys. $(\mathrm{mol} \%)$

\begin{tabular}{llllllll}
\hline Nominal composition & Phase & \multicolumn{6}{c}{ Chemical composition } \\
\hline & & $\mathrm{Nb}$ & $\mathrm{Mo}$ & $\mathrm{W}$ & $\mathrm{Si}$ & $\mathrm{Hf}$ & $\mathrm{C}$ \\
$\mathrm{Nb}-16 \mathrm{Si}-5 \mathrm{Mo}-5 \mathrm{~W}$ & $\mathrm{Nb}_{\mathrm{ss}}$ & 84.26 & 6.90 & 8.34 & 0.50 & - & - \\
& $\mathrm{Nb}_{5} \mathrm{Si}_{3}$ & 60.90 & 0.38 & 0.36 & 38.36 & - & - \\
Nb-16Si-5Mo- & $\mathrm{Nb}_{\mathrm{ss}}$ & 65.76 & 4.63 & 28.34 & 0.12 & 0.71 & 0.71 \\
15W-5Hf-5C & $\mathrm{Nb}_{5} \mathrm{Si}_{3}$ & 49.92 & 0.40 & 0.40 & 34.88 & 7.41 & 6.99 \\
& $\mathrm{NbC}$ & 36.86 & 0.06 & 0.33 & - & 15.25 & 47.50 \\
\hline
\end{tabular}

\section{2 引張クリープ特性}

試験温度 $1773 \mathrm{~K}$ での引張クリープ試験により得られた Nb-20Si-5Mo と Nb-20Si-5Mo-5Hf-5C のクリープ曲線を Fig. 3 に示す.な扔，Fig. 3(a) と（b)にとれぞれ示された $\mathrm{Nb}-20 \mathrm{Si}-5 \mathrm{Mo}$ の応力 $20 \mathrm{MPa}$ 打よび $\mathrm{Nb}-20 \mathrm{Si}-5 \mathrm{Mo}-5 \mathrm{Hf}-$ $5 \mathrm{C}$ の $40 \mathrm{MPa}$ の曲線は, 試験片がまだ破断まで至っていな い.それぞれ逆 S 字型のクリープ曲線が観察された。応力 が大きくなるほど, 破断時間は短くなり伸びは大きくなる傾 向がある. $40 \mathrm{MPa}$ ではクリープ曲線形状は大きく異なり, Hf とCを添加した合金はクリープ破断寿命が著しく増加し ていることがわかる. Fig. 4 は変形中のクリープ速度の変化 を明瞭に示すために，それら合金のクリープ速度と経過時間 の関係を両対数グラフで示したものである. Fig. 4 からク リープ速度は時間の経過とともに最初は次第に減少し, 極小 值を示したのちに増加しているが, 概して定常クリープは明 瞭でなく, 全体的には加速クリープの領域が最も支配的であ る. 最小クリープ速度を示す時間は負荷応力が小さくなるほ ぞ長時間側にずれるとともにその時間の範囲も広くなり, 明

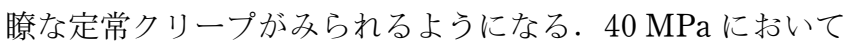
Hf と C を添加した合金では，ひずみ速度は初期のから低く 強化が認められる.

Fig. 5 にクリープ破断時間と応力抢よび伸びの関係をそれ
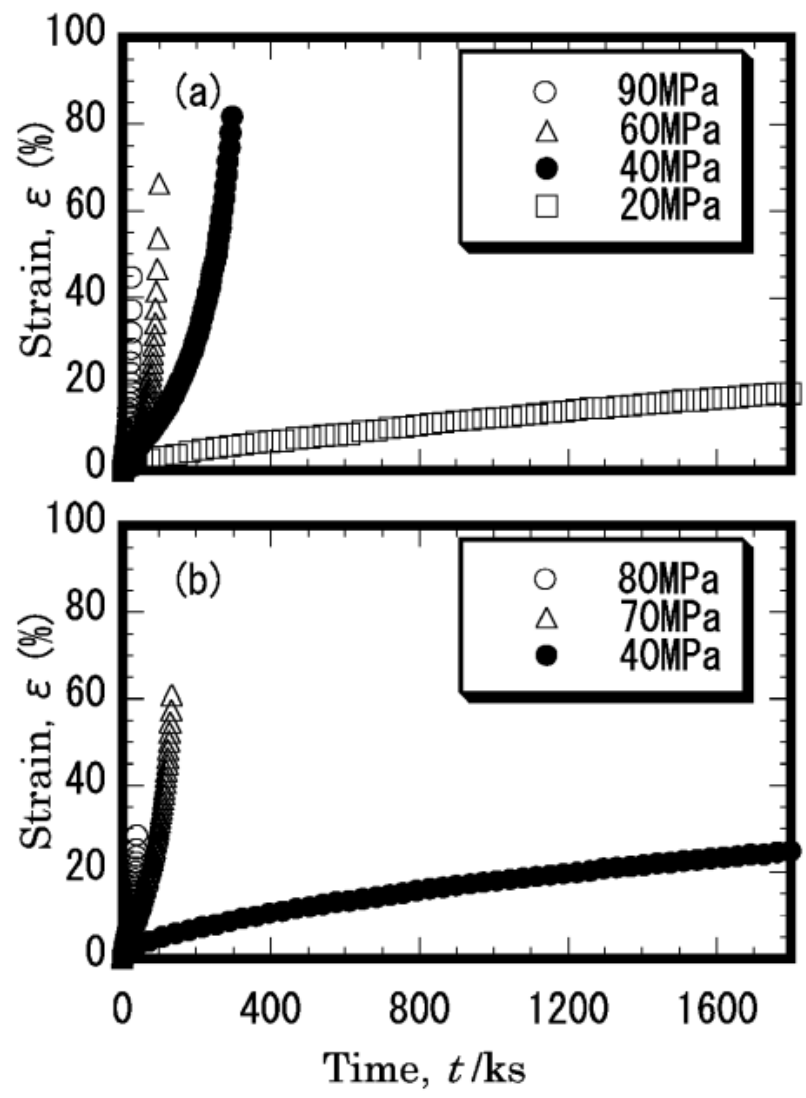

Fig. 3 Creep curves of $\mathrm{Nb}-20 \mathrm{Si}-5 \mathrm{Mo}(\mathrm{a}), \mathrm{Nb}-16 \mathrm{Si}-5 \mathrm{Mo}-$ $10 \mathrm{~W}(\mathrm{~b}), \mathrm{Nb}-20 \mathrm{Si}-5 \mathrm{Mo}^{-}-5 \mathrm{Hf}-5 \mathrm{C}$ (c) and $\mathrm{Nb}-16 \mathrm{Si}-5 \mathrm{Mo}-15 \mathrm{~W}-$ $5 \mathrm{Hf}-5 \mathrm{C}(\mathrm{d})$ at $1773 \mathrm{~K}$.
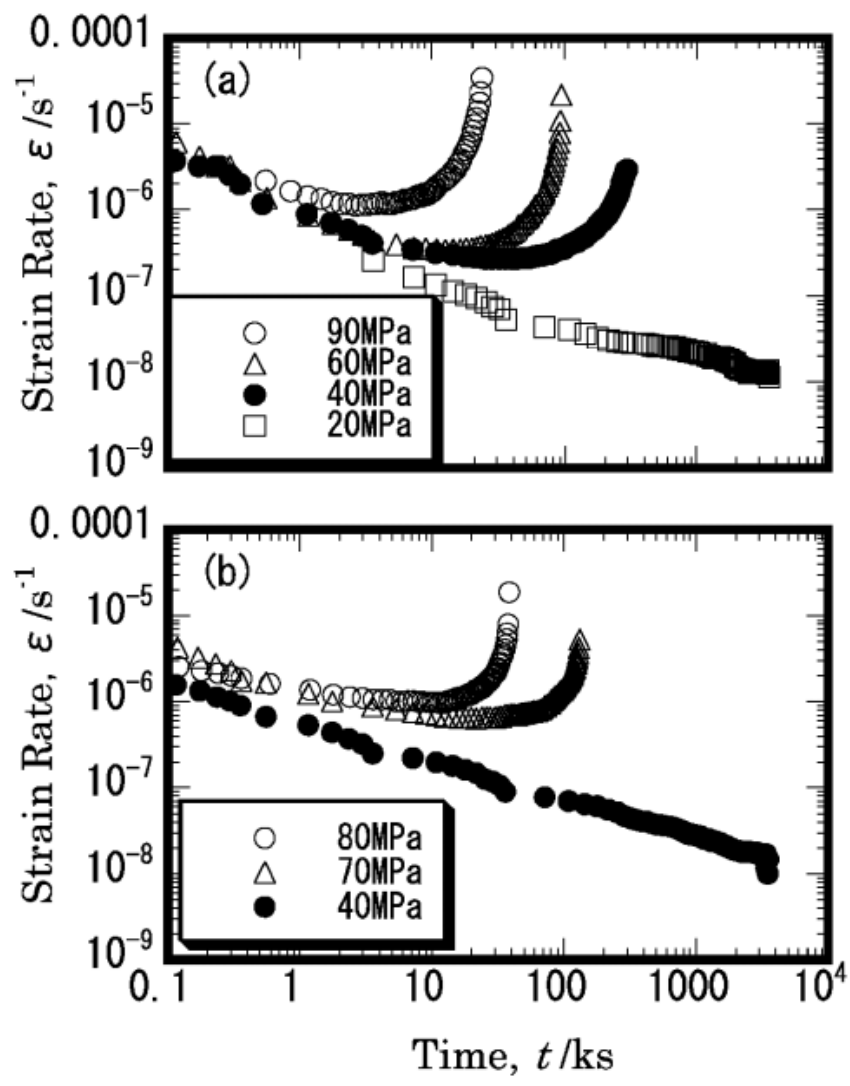

Fig. 4 Strain rate vs. creep time curves of $\mathrm{Nb}-20 \mathrm{Si}-5 \mathrm{Mo}$ (a), $\mathrm{Nb}-16 \mathrm{Si}-5 \mathrm{Mo}-10 \mathrm{~W}(\mathrm{~b}), \mathrm{Nb}-20 \mathrm{Si}-5 \mathrm{Mo}-5 \mathrm{Hf}-5 \mathrm{C}$ (c) and $\mathrm{Nb}-$ $16 \mathrm{Si}-5 \mathrm{Mo}-15 \mathrm{~W}-5 \mathrm{Hf}-5 \mathrm{C}(\mathrm{d})$ at $1773 \mathrm{~K}$. 
ぞれ示す. Fig. 5(a)において, Nb-20Si-5Mo に比べて Nb$20 \mathrm{Si}-5 \mathrm{Mo}-5 \mathrm{Hf}-5 \mathrm{C}$ のクリープ破断時間は高応力側では差が

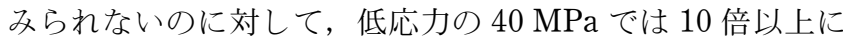
および，これは主として炭化物の分散に伴う強化への寄与に よるものと考えられる. Farkas ら ${ }^{12-14)}$ は， Nb-1Zr-0.1C 合 金では高応力側で炭化物粒子によるクリープ強度改善の効果 はほとんど無いが，低応力側でクリープ速度が急激に低下す ることを報告し，炭化物粒子によってサブグレインの成長が 押さえられることが，長時間側でのクリープ速度低下の原因 と推測されている。 また Fig. 5 (a)で，Nb-20Si-5Mo と $\mathrm{Nb}-20 \mathrm{Si}-10 \mathrm{Mo}$ を比較すると, Mo 量の増加によってかえっ て低応力側で破断時間が減少しているが，その原因は明らか ではない.一方, Fig. 5 (c)の Nb-16Si-5Mo-5W と Nb16Si-5Mo-10W の比較では $\mathrm{W}$ 量の増加によって破断時間は 大きく増加している，さらに Nb-16Si-5Mo-15W は，負荷 の途中で破断したため，試験を実施することが出来なかった のに対して, Nb-16Si-5Mo-15W-5Hf-5C は, $1773 \mathrm{~K}, 100$ $\mathrm{MPa}$ で破断時間が 477 時間と長く，非常に優れたクリープ 特性を示した．組織観察の結果と総合して，Hf と C の添加 による結晶粒界や相界面への炭化物の析出が粒界などの強化 に役立ち, 併せて延性も改善されたものと推測される。

Fig. 5(b)，(d)にクリープ破断時間と破断伸びの関係を示 す。破断伸びは全体に大きく，概して低応力の場合ほど破断 伸びは増加する傾向が見られる，ただし強度の大きい合金ほ
ど伸びは小さくなっており, 最も高い強度を示した $\mathrm{Nb}$ 16Si-5Mo-15W-5Hf-5C では実験した範囲での伸びはおよ そ20\%以下である。

Fig. 6 は $\mathrm{Nb}$ 基合金の最小クリープ速度 $\left(\dot{\varepsilon}_{\mathrm{m}}\right)$ と応力の関係 を示したものである. 応力の低下とともに $\varepsilon_{\mathrm{m}}$ は小さくなる.

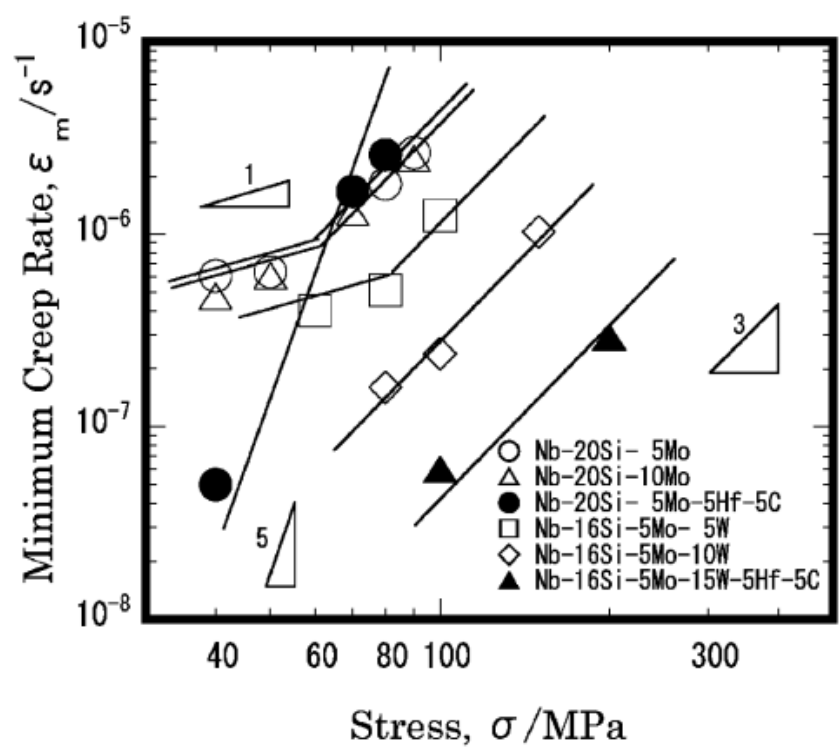

Fig. 6 Stress dependence of minimum creep rates for various $\mathrm{Nb}$-based alloys.
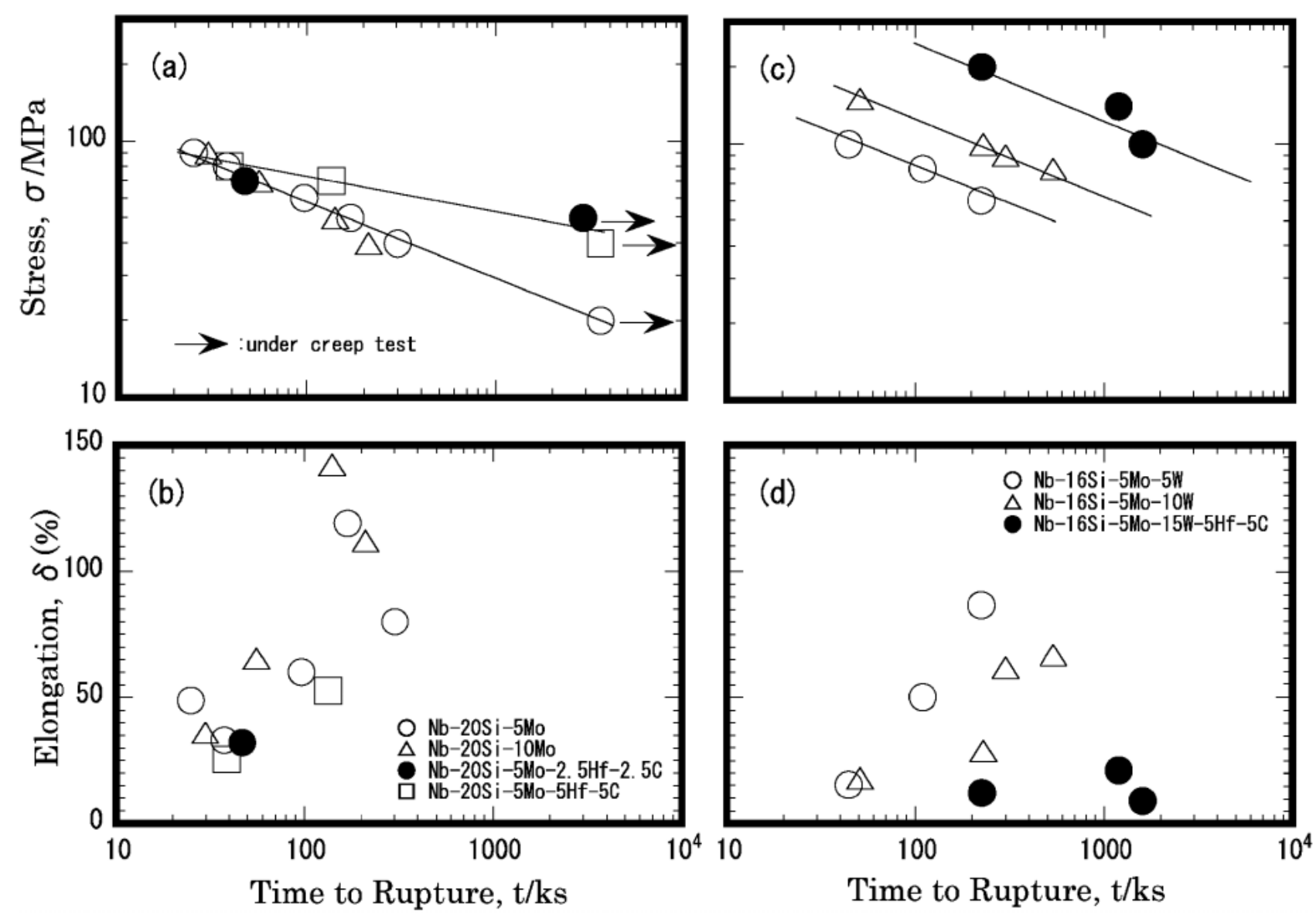

Fig. 5 Creep rupture properties of $\mathrm{Nb}$-based alloys tested. 
Fig. 5 では応力の低下に伴ってクリープ破断時間は増加して いるため, $\dot{\varepsilon}_{\mathrm{m}}$ の低下によって破断時間は増加する. $\dot{\varepsilon}_{\mathrm{m}}$ の值 は合金ごとに大きく異なり, Nb-20Si-5Mo-5Hf-5C の低応 力 $(40 \mathrm{MPa})$ 側での $\dot{\varepsilon}_{\mathrm{m}}$ や $\mathrm{W}$ 添加量の多い合金の $\dot{\varepsilon}_{\mathrm{m}}$ は小さ く, 炭化物の析出や固溶によって大きく強化されることが分 かる. 図の上方に位置するクリープ強度の小さい合金 $(\mathrm{Nb}-$ $20 \mathrm{Si}-5 \mathrm{Mo}, \mathrm{Nb}-20 \mathrm{Si}-10 \mathrm{Mo}$ ) では, 応力指数 $n$ 值の異なる二 つの領域が見られ, 高応力側での $n$ 值は約 3 であるが, 低 応力側では 1.0 強のごく小さい值を示している. 一方, $\mathrm{Nb}-$ $20 \mathrm{Si}-5 \mathrm{Mo}-5 \mathrm{Hf}-5 \mathrm{C}$ 合金だけは $n=5$ 付近の值を示した. $\mathrm{Nb}_{5}$ $\mathrm{Si}_{3}$ の単相合金の特性についての報告 ${ }^{15)}$ の中で Subramannian らは, $1473 \mathrm{~K}$ での $n$ 值は約 1 , 活性化エネルギーは 234 $\mathrm{kJ} / \mathrm{mol}$ で, クリープは $\mathrm{Nb}$ の拡散によって支配されている と報告しているが, 高応力側では, 単相の $\mathrm{Nb}_{5} \mathrm{Si}_{3}$ は部分的 にき裂が発生し伝ぱしているため, $n$ 值が見かけ上高くなる と指摘している。ささらに， Nb-10Si の $1373 \mathrm{~K}$ から $1573 \mathrm{~K}$ での $n$ 值は $3 \sim 4$ で, クリープ速度は $\mathrm{Nb}_{5} \mathrm{Si}_{3}$ より 1 桁大き いと報告している16)。 また, 花田らは, $1573 \mathrm{~K}$ から $1773 \mathrm{~K}$ に抢ける Nb-20Mo-10W の $n$ 值は 4〜 5, 活性化エネルギー は $655 \mathrm{~kJ} / \mathrm{mol}$ で, $\mathrm{Nb}$ 中の W の拡散に関する活性化エネル ギー $(653 \mathrm{~kJ} / \mathrm{mol})$ に近く, クリープ変形に打いて $\mathrm{Nb}$ 中の $\mathrm{W}$ の拡散が変形を律速していることを報告している17).さ らに，また著者らが以前に求めた $\mathrm{Nb}-16 \mathrm{Si}-10 \mathrm{Mo}-15 \mathrm{~W}$ の $1773 \mathrm{~K}$ での $n$ 值は $3.2 \sim 4.2$ であるが, 活性化エネルギーは $677 \mathrm{~kJ} / \mathrm{mol}^{18)}$ で, 上記の $\mathrm{Nb}$ 中の W の拡散に関する活性化 エネルギーにほぼ等しいことを示した．以上のことから， $\mathrm{Nb}_{5} \mathrm{Si}_{3}$ の $n$ 值と活性化エネルギーは $\mathrm{Nb}$ 固溶体に比べて小 さく, $\mathrm{Nb}_{\mathrm{ss}} / \mathrm{Nb}_{5} \mathrm{Si}_{3}$ 二相合金では固溶体合金に近い值を示す と考えられる. 以上の事実から，一部の合金に認められた $\hat{\varepsilon} \mathrm{m}$ の応力依存性に打和 2 つ領域の低応力側ではシリサ イド, 高応力側では固溶体がクリープ変形を律速しているも のと推測される。 また, Hf と C を含む三相合金では, 粒 界, 相境界や $\mathrm{Nb}_{\mathrm{ss}}$ 内にも炭化物の分散が見られる.この合 金は $\mathrm{Nb}_{\mathrm{ss}}$ や二相合金に比べ $n$ 值が大きく,さらにクリープ 変形後のシリサイド中に炭化物の析出が見られ, 二相合金と は変形機構が異なるものと考えられる. 今後, クリープ変形 した後の転位組織などを観察して，さらに考察を深めること が必要である。

\section{3 破断面と組織}

クリープ破断試験後, 試験片を引張軸に対して平行に切断 した破断面近傍の BEI による代表的な組織を Fig. 7 に示す.

Fig. 7 (a)，(b) は応力 $60 \mathrm{MPa}$ と $100 \mathrm{MPa}$ で試験した $\mathrm{Nb}$ 16Si-5Mo-5W の組織を示す。低応力長時間で破断したもの は，組織が大きく塑性変形したことがわかる，また，大きな ボイドらしい欠陥が主に二相界面に観察され一方, 高応力短 時間で破断したもの (b)は，クリープ変形中に負荷応力の影 響を受けない試験片のつかみ部の組織 Fig. 1(a) と比較して 相違はほとんど見られない。また， Nb-20Si-5Mo-2.5Hf$2.5 \mathrm{C}$ のシリサイド中には $1 \mu \mathrm{m}$ 以下の小さな粒子が見ら れ，クリープ試験中に析出した炭化物と思われる. Table 2 に示した試験前の組織定量の結果, 三相合金のシリサイド中 に Hf とCが数\%含まれおり，それが試験中のクリープ変形 に加速されて析出したものと推測される.

Fig. 8 にクリープ破断面の SEM 写真を示す. Fig. 8(a) と (b) は応力 $60 \mathrm{MPa}$ と $100 \mathrm{MPa}$ で試験した Nb-16Si-5Mo5W の破断面の SEM 写真である. 低応力による破断面 (a) では，全般に小さな凹凸や大きな空洞が見られるのに対し て, 高応力短時間で破断した破面 (b)では固溶体部分に大き な割れが見られる。 また $\mathrm{Nb}-16 \mathrm{Si}-5 \mathrm{Mo}-15 \mathrm{~W}$ (c) は, 負荷の 途中で破断した試験片破面であるが，脆性的破壊の様相を示 し，固溶体部分の粒内割れや界面のはく離が見られる。一 方, 炭化物が分散した Nb-16Si-5Mo-15W-5Hf-5C では, 全体に小さな凹凸が見られ，固溶体部分の大きな割れは認め られない。ただし，局所的には脆性破壊らしき箇所も見られ た。

\section{4. 結言}

アーク溶解で作製した $\mathrm{Nb}_{\mathrm{ss}} / \mathrm{Nb}_{5} \mathrm{Si}_{3}$ 系合金にて，組織およ び固溶強化が引張クリープ特性におよぼす影響を研究し, 以 下の結論を得た。

(1) Mo に比べて W の添加はクリープ強度を大きく改善 する。

(2) Mo や W の添加量の多い Nb-16Si-5Mo-15W では, $1773 \mathrm{~K}$ の引張負荷中に脆性破壊を生じたが, Hf と C を添 加した合金系では高温の延性が改善され，クリープ破断時間
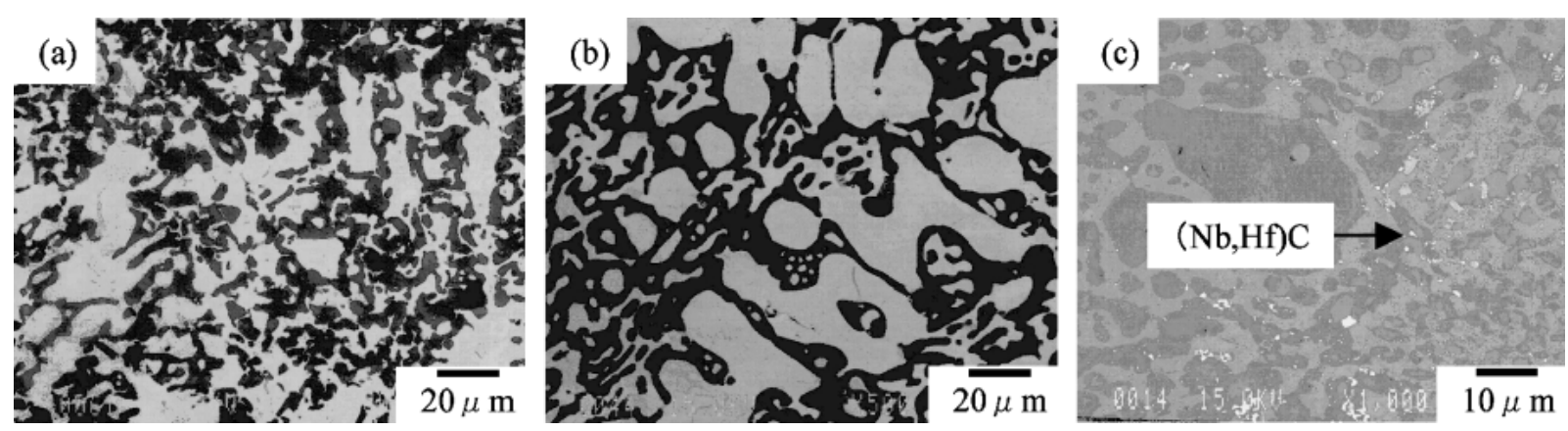

Fig. 7 BEI images of Nb-based alloys, creep ruptured at $1773 \mathrm{~K}$.

(a) Nb-16Si-5Mo-5W, under $60 \mathrm{MPa}$. (b) Nb-16Si-5Mo-5W, under $100 \mathrm{MPa}$. (c) Nb-20Si-5Mo-2.5Hf-2.5C, under $70 \mathrm{MPa}$. 

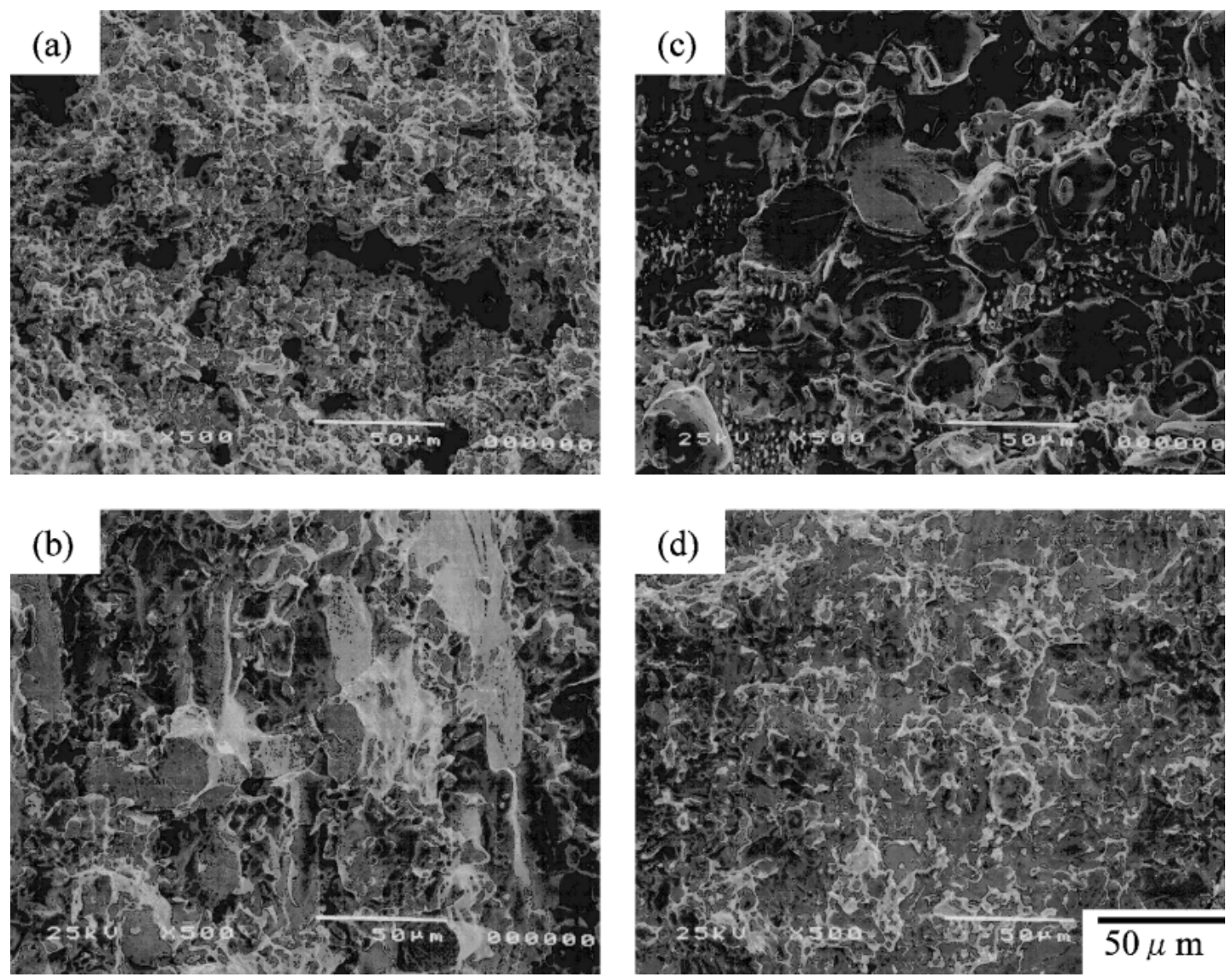

Fig. 8 SEM images of surface of $\mathrm{Nb}$-based alloys, creep ruptured at $1773 \mathrm{~K}$.

(a) $\mathrm{Nb}-16 \mathrm{Si}-5 \mathrm{Mo}-5 \mathrm{~W}$, under $60 \mathrm{MPa}$. (b) $\mathrm{Nb}-16 \mathrm{Si}-5 \mathrm{Mo}-5 \mathrm{~W}$, under $100 \mathrm{MPa}$. (c) $\mathrm{Nb}-16 \mathrm{Si}-5 \mathrm{Mo}-5 \mathrm{~W}$, ruptured during loading.

(d) $\mathrm{Nb}-16 \mathrm{Si}-5 \mathrm{Mo}-5 \mathrm{~W}$, under $100 \mathrm{MPa}$.

も著しく延長された．これは炭化物の分散の効果と考えられ る.

(3) 炭化物の分散によって $\mathrm{Nb}-16 \mathrm{Si}-5 \mathrm{Mo}-15 \mathrm{~W}-5 \mathrm{Hf}-5 \mathrm{C}$ は, $1773 \mathrm{~K}, 100 \mathrm{MPa}$ のクリープ破断時間が 500 時間に近 く, 非常に優れたクリープ特性を示す.

本研究は株式会社超高温材料研究所が新エネルギー・産業 技術総合開発機構 $(\mathrm{NEDO})$ 上り受託して実施した研究の一部 である。また，本研究の遂行に関し，クリープ試験について の助言および協力をいただいた加藤英二氏に深く感謝します.

\section{文献}

1) W.-Y. Kim, H. Tanaka, A. Kasama, R. Tanaka and S. Hanada: Intermetallics 9 (2001) 521-527.

2) W.-Y. Kim, H. Tanaka, A. Kasama and S. Hanada: Intermetallics $\mathbf{9}(2001) 827-834$

3) H. Tanaka, W.-Y. Kim, A. Kasama, R. Tanaka and Y. Mishima: J. Japan. Inst. Metals 66 (2002) $772-777$.

4) W.-Y. Kim, H. Tanaka and S. Hanada: Intermetallics 10 (2002) 625-634.

5) W.-Y. Kim, H. Tanaka and S. Hanada: J. Mater. Sci. 37 (2002)
$2885-2891$.

6) H. Tanaka, W.-Y. Kim, A. Kasama, R. Tanaka and Y. Mishima: J. Japan. Inst. Metals 66 (2002) 101-106.

7) W.-Y. Kim, H. Tanaka, A Kasama and S. Hanada: J. Alloy. Compd. 333(2002) 170-178.

8) D. M. Shah, D. L. Anton, D. P. Pope and S. Chin: Mater. Sci. Eng. A. 192 (1995) 658-672.

9) R. Gnanamoorthy and S. Hanada: Scr. Mater. 34(1996) 9991003.

10) R. M. Nekkanti and D. M. Dimiduk: MRS Symp. Proc. 194 (1990) pp. 175-182.

11) M. G. Mendiratta, J. J. Lewandowski and D. M. Dimiduk: Metall. Trans. A. 22A (1991) 1573-1583.

12) M. J. Davidson, M. Biberger and A. K. Mukherjee: Scr. Metall. Mater. 27 (1992) 1829-1834.

13) D. M. Farkas and A. K. Mukherjee: Mater. Sci. Eng. A. 222(1997) 11-27.

14) D. M. Farkas and A. K. Mukherjee: J. Mater. Res. 11(1996) 2198-2205.

15) P. R. Subramanian, T. A. Parthasarathy, M. G. Mendiratta and D. M. Dimiduk: Scr. Metall. Mater. 32 (1995) 1227-1232.

16) D. M. Dimiduk, M. G. Mendiratta and P. R. Subramanian: Structural Intermetallics, ed. By R. Darolia, J. J. Lewandoski, C. T. Liu, P. L. Martin, D. B. Miracle and M. V. Nathal, (TMS, Warrendale, PA, 1993) pp. 619-630.

17) S. Hanada: Annual Report on R \& D of Technology of Refractory Metals (JUTEMI) (1998) pp. 75-90.

18) Annual Report on R \& D of Technology of Refractory Metals (JUTEMI) (2000) pp. 60-77. 